Article

\title{
Managerial Shareholding and CSR: Does Internal Control Quality Matter?-Evidence from China
}

\author{
Mingyuan Guo * and Shuyu Shen \\ College of Management and Economics, Tianjin University, Tianjin 300072, China \\ * Correspondence: guomingyuan@tju.edu.cn
}

Received: 15 July 2019; Accepted: 1 August 2019; Published: 3 August 2019

\begin{abstract}
This paper uses the data of Corporate Social Responsibility (CSR) performance of A-share listed companies in China from 2013-2017 as sample to study on the impacts of managerial shareholding on CSR performance. By dividing the sample into mandatory disclosure group and voluntary disclosure group, we first empirically test the impacts of managerial shareholding on CSR performance. Then, we discuss the role of internal control quality in the impacts of managerial shareholding on CSR performance. Panel data models are employed in the empirical research and robust test. The empirical results show that: Firstly, in mandatory disclosure group, managerial shareholding has no significant impacts on CSR performance. In voluntary disclosure group, managerial shareholding has a positive impact on CSR performance. Secondly, in voluntary disclosure group, internal control quality has a positive role in the impacts of managerial shareholding on CSR performance, but this positive role cannot be supported empirically in mandatory disclosure group. Overall, these findings indicate that CSR performance is influenced by managerial shareholding and varies with CSR disclosure behaviors. The results of robust test also support this conclusion. Finally, we put forward that it would be a good choice for the companies to implement long-term equity incentives and improve internal control quality to promote CSR performance.
\end{abstract}

Keywords: managerial shareholding; CSR; internal control quality; mandatory disclosure; voluntary disclosure; panel data models

\section{Introduction}

At the beginning of the 20th century, scholars began to doubt the concept of "maximizing shareholder's interests" in traditional theory of corporate governance. They proposed a claim on corporate social responsibility, which called for the company's liability for shareholders and employees, as well as for environment, consumers and society (Sheldon [1]; Panapanaan et al. [2]; Spiller [3]). This idea has been widely accepted by multinational corporations. With the implementation of CSR assessment system for the suppliers in international procurement, Chinese companies begun to state their social responsibilities in the form of notes in their annual report. As reform and opening-up progress further, Chinese companies' CSR awareness is in line with the world.

As the largest developing country in the world, China is an important part of the world economy. Moreover, Chinese companies play an important role in China's economic development. Although the reform and opening-up has been going on for more than 30 years, it means neither that China's economic operation mode and the allocation of funds are already marketized nor that China's market economy is mature. The foreign capital in Chinese market still needs to go native. Our research can help multinational corporations understand Chinese characteristics and formulate reasonable policies to operate effectively and efficiently. Chinese government has committed to promoting the fulfillment of CSR of listed companies, as well as appealing for CSR information disclosure. In 2006, the newly revised "China Corporate Law" clearly stipulated that companies must abide by social morality, 
business ethics, and social responsibilities, which transforms CSR performance from economic ethics into legislative practice. In September 2016, the Shenzhen Stock Exchange (SZSE) issued "Guidelines for Social Responsibility of Listed Companies", which gave a detailed explanation of the social responsibilities required. Listed companies are encouraged to adopt CSR reporting system to regularly disclose their CSR information. In May 2008, the Shanghai Stock Exchange (SSE) promulgated "Notice on Strengthening the Social Responsibility of Listed Companies", which advocated listed companies to pay attention to the sustainable development of environment, economy and society. In December 2008, SZSE and SSE made a decision on compulsory issuance of CSR report for the listed companies, which were included in the four stock indexes (SZSE 100 Index, SSE Financials, SSE Overseas-listing, and SSE Corporate Governance Index). The power of Chinese government in promoting CSR is strong. As a result, it is very meaningful to choose Chinese market as sample with regard to our research topic. In addition, according to the actual situation of China, this paper divides the full sample into mandatory CSR disclosure group and voluntary CSR disclosure group.

In recent years, lots of literatures have discussed the influence factors of CSR performance, such as shareholding structure (Qu et al. [4]), CEO characteristic (Karim et al. [5]), policy environment (Hadley et al. [6]), etc. Some scholars concluded that managerial shareholding had an important impact on enterprises' CSR performance (Yin et al. [7]; Li and Ma [8]; Qi [9]). In addition, effective internal controls are reasonable assurances for the truth and completeness of disclosed information. The Committee of Sponsoring Organizations of the Treadway Commission (COSO) Report (2013) and China's "Basic Standards for Internal Control of Enterprises" (2008) also extended the scope of internal control to CSR. A lot of literature has proved that internal control quality has great impact on CSR (Feng et al. [10]; Pirvu et al. [11]; Chen and Liu [12]). This paper attempts to investigate the impact of managerial shareholding on CSR performance and whether internal control quality promotes the impacts of managerial shareholding on CSR performance.

This paper puts forward research hypothesis that managerial shareholding has positive impacts on CSR performance and the impacts are influenced by internal control quality. According to research hypothesis, we construct panel data models respectively to study the impact of managerial shareholding on CSR performance. Furthermore, we use cross-terms to study the role of internal control quality in the impact of managerial shareholding on CSR performance. We estimate panel data models both in empirical research and robust test.

Compared with previous literatures, the contributions of this paper are as follows: (1) Firstly, there are a few literatures on managerial shareholding and CSR. However, for the measurement of managerial shareholding, most studies focus on the percentage of shares held by managers (Albring and Xu [13]; Korczak and Liu [14]), not the market value of managerial shareholding. This paper takes the company's market value of managerial shareholding into consideration, because market value has an important impact on its corporate governance and CSR performance. Furthermore, we construct two dummy variables to respectively indicate whether the ratio and market value of managerial shareholding are higher than industry average. By measuring managerial shareholding in various way, we offer a more comprehensive view to study on the impact of managerial shareholding on CSR performance. (2) Secondly, we aim to study on the different impacts of managerial shareholding on CSR performance in different CSR disclosure group. As a result, this paper divides the full sample into mandatory CSR disclosure group and voluntary CSR disclosure group. (3) Many scholars have analyzed the role of internal control quality in the relationships, such as organizational justice and employee fraud (Rae and Subramaniam [15]), R\&D investment and enterprise performance (Sun et al. [16]), and management power and earnings management (Hu [17]). This paper studies on the role of internal control quality in the impact of managerial shareholding on CSR performance. (4) Finally, based on the conclusion, this paper puts forward some effective suggestions. Considering the above contributions, the research in this paper is in-depth and significative. 
This paper is organized as follows: Section 2 reviews and summarizes the literature. Section 3 presents the hypotheses, variables, models and data of this paper. Section 4 conducts an empirical analysis and discusses the results. Section 5 summarizes and proposes some suggestions.

\section{Literature Review}

The European Commission defines CSR as "a concept whereby companies integrate social and environmental concerns in their business operations and in their interaction with their stakeholders on a voluntary basis" (European Commission, 2001). Stakeholder theory is closely linked to CSR for it provides the answer to the question of for whom a corporate is responsible (Driver et al. [18]; Laczniak et al. [19]). Generally, a stakeholder can be any person, group, organization, society and environment. Frederikc et al. [20] divided them into direct stakeholders, such as investors and employees, and indirect stakeholders, such as the government and the public. It was the first time that the differences between internal and external factors are considered. Direct stakeholders are the decision-makers, managers and workers of business activities and they can obtain the first-hand information of the company easily. As the actual operator of the company, managers should come up with an exhaustive list of stakeholders and their interests, thus enabling them to make sure that the company engages in a fair balancing of interest with the firm's social system (Mitchell et al. [21]). What's more, according to the asymmetric information problem, Kuriakose [22] described a situation where some stakeholders had more information than others and were given more powerful ability to rob excess benefits. As well, Brown et al. [23], invoking the agency cost theory, indicated that managers may benefit themselves using firm information through corporate philanthropy while shareholders incur a loss by spending on charity. Thus, disclosing corporate information is to reduce the information asymmetry of stakeholders and performing CSR is to balance the interests of various stakeholders. Disclosing CSR with high quality has been proved with positive economic consequences, such as reducing financing costs (Zhao et al. [24]), lowing M\&A risk (Arouri et al. [25]), enhancing financial performance (Orlitzky [26]), improving market value (Qu [4]) and so on. Additionally, there are many literatures which have discussed the factors affecting CSR performance.

We mainly review some literatures related to managerial shareholding, internal control quality and CSR disclosure behavior.

\subsection{Managerial Shareholding and CSR}

As incentive methods for managers, managerial shareholding gives managers both monetary benefits and decision-making power. Early agency theories (Kalay [27]) suggest that holding shares encourage managers to attach more importance to the long-term development of the company. Moreover, holding shares actively protect the interests of stakeholders and maintain the stability of development (Zahra et al. [28]). However, the Residual Claim theory believes that when managers hold shares, the belief of maximizing shareholders' interests is strengthened and the enterprise's CSR performance are worsened. Friedman [29] saw CSR as an agency problem and suggests that CSR has a negative effect on corporate financial performance because a firm's CSR entail costs. In the last decade, various empirical studies have drawn different conclusions on the impact of managerial shareholding on CSR. Yin et al. [7] found that managerial shareholding weakened the opportunistic behavior of management in listed companies in China and had a significantly positive effect on the disclosure of CSR. Karim et al. [5] found that CSR performance was negatively correlated with CEO's short-term salary, but positively correlated with their options' market value, indicating that CSR was more used as a business strategy to enhance corporate value, rather than means of seeking personal interests. On the contrary, Wang et al. [30] found that with inevitable asymmetric information, managerial shareholding indulged the "entrenchment effect" of information disclosure. The higher the ratio of managerial shareholding, the worse the quality of CSR performance. Li and Ma [8] used the data of A-share listed companies in China from 2012-2016 as sample. They found that as managerial shareholding ratio increasing, CSR performance first rose and then fell with an inverted-U shape. 
Managerial shareholding is also a form of long-term compensation, which are generally considered to be the main incentive to prevent managers from generating self-interested behavior. Luo et al. [31] pointed out that the higher the managerial compensation, the more CSR performance to maintain the rationality of high compensation. Cullinan et al. [32] indicated that there was a significant correlation between the CSR performance and managerial compensation. Bouslah et al. [33] examined the correlation between risk-taking incentives and social irresponsibility of American CEOs. Their results suggested that CEO risk-taking incentives are positively related to socially irresponsible behaviors before the 2007 financial crisis. However, the results after the 2007 financial crisis cannot support this finding, which may due to the increased scrutiny regarding compensation packages. It confirmed that risk-taking incentives embedded in the CEO compensation scheme do have implications towards CSR activities. Qi [9] used the data of A-share listed companies in China from 2012-2015 as sample. It is concluded that the higher the long-term managerial salary, the more significant the correlation between financial performance and social performance. However, after studying Fortune's ranking of America's most admired companies, Focke et al. [34] demonstrated that these firms' total compensation is on average $8 \%$ lower than others, indicating that managers are willing to trade off career benefits from working for a company that is publicly admired against additional monetary benefits. Li and $\mathrm{Gu}$ [35] concluded that the reduction in managerial compensation led to a more harmonious working environment and the improvement of CSR performance. Managerial compensation had a negative impact on CSR performance.

\subsection{Internal Control and CSR}

Internal control is a series of measures, methods and rules targeted at protecting the company's assets, as well as providing authenticity and reliability for the disclosed information. Many scholars have studied the relationship between internal control and CSR performance. Wang et al. [36] thought that people-oriented internal control framework had the function to supervise CSR and mitigate the conflicts of interests in stakeholders. Liu [37] thought that internal control could create a friendly internal environment for companies to fulfill their social responsibilities. Pirvu et al. [11] stated that strict internal controls actively promoted all social responsibilities associated, including economy, society and environment. Using non-financial A-share listed companies in SSE as sample, Feng et al. [10] found that high internal control quality could effectively promote CSR. Shao [38] proved that there was a positive correlation between internal control quality and carbon information disclosure. Drobetz et al. [39] constructed a CSR performance index for multinational shipping companies and found that companies with high financial leverage are more inclined to keep a good relationship with relevant stakeholders. Che and Su [40] conducted an empirical study using all listed companies which voluntarily disclosed CSR in China from 2010 to 2015 as sample. They found that high-quality CSR reports could make up for the harm of violations to the legitimacy of enterprises. Huang et al. [41] found that the Big Four global accounting companies paid more attention to CSR performance, which indirectly verified the guiding role of audit opinions on CSR performance.

Hua [42] put forward the concept of "internal control of social responsibility", which referred to an internal control framework with targets of CSR. Qi [43] innovatively introduced CSR indicators when evaluating the internal control efficiency of construction enterprises. Yongming [44] empirically verified the positive interaction of internal control and CSR performance. Zhang [45] theoretically proved the importance of the integration of internal control and CSR, which could bring " $1+1>2$ " effect to corporate governance.

\subsection{Mandatory Disclosure and Voluntary Disclosure of CSR}

CSR disclosure is the behavior of a company to disclose its social responsibility in the form of reports, appendices or others. CSR disclosure may due to external pressure and self-interested (Xiao [46]). CSR disclosure generally has two basic forms, including mandatory disclosure and voluntary disclosure. 
Mandatory disclosure means that the company discloses CSR according to the requirements of the government. Chen and Zeng [47] used the data of A-share listed companies which issued CSR reports in China from 2009 to 2011 as sample. They found that companies responded proactively to the pressure coming from the government, which was consistent with Hadley's study [6]. Through comparing the CSR disclosed before and after the promulgation of the "Guidelines for the Governance of Listed Companies", Shen and Jin [48] concluded that CSR disclosure in China had increased significantly in quantity rather than in quality. For the purpose of policy evaluation, Tian and Wang [49] found that the insufficient penalty for CSR performance fraud significantly increased the stock crash risk of the companies. $\mathrm{Wu}$ [50] selected mandatory disclosure companies as sample to study the factors affecting CSR. He found that the size of the company and the proportion of state-owned shares had a significantly positive impact on CSR.

By contract, voluntary disclosure reflects the will of the company more. Scholars hold both positive and negative attitudes towards voluntary disclosure. Some scholars consider that CSR performance gains public recognition and enhance corporate reputation, which reduces operating risk and bring business resources to the company (Mzembe et al. [51]). Some scholars believe that voluntary disclosure is to dilute the negative news of the company and avoid the loss of reputation caused by irresponsible corporate strategy. CSR performance is a means of survival in harsh business environment (López-González et al. [52]), and also a "self-interesting tool" (Quan et al. [53]). Using an unbalanced panel data containing more than 4500 multinational companies over 19 years as sample, Kang et al. [54] found that the fulfillment of CSR is not due to idle resources, but to make up for the lack of CSR in the past. From the perspective of risk management, Frederiksen [55] verified CSR performance as strengthening public-relations. Furthermore, Jahn [56] found that including bad news in CSR report attribute to the honesty of the company, which ultimately made the effect of bad news insignificant.

\section{Research Design}

\subsection{Hypothesis Development}

CSR performance is the performance of the company's fulfillment of CSR. Through the company's CSR disclosure, we can appraise the company's CSR performance. In this section, we put forward research hypothesis that managerial shareholding has positive impacts on CSR performance and the impacts are influenced by internal control quality.

\subsubsection{Managerial Shareholding and CSR}

CSR performance is not a short-term speculation. The principal-agent theory develops the opinion that the more shares held by managers, the more their personal interests converge with the interests of the company. The decline in agency costs leads to the decline in the cost of CSR fulfillment and disclosure (Mohd et al. [57]), which in turn improves the quality of CSR performance. What's more, CSR performance is constrained by corporate resources. Managerial shareholding can significantly influence managers' decisions on how to allocate the company's resource. The higher the percentage of shares held by management, the more reasonable the allocation of resources is (Lazonick [58]). As a result, we propose Hypothesis 1:

\section{H1. Managerial shareholding ratio has a positive impact on CSR performance.}

As far as the managers' personal monetary benefits are considered, the equity incentives make sense only if the market price is involved. The same managerial shareholding ratio may have different motivations, if the company's market values are different. The shares held by managers may not be converted into cash immediately, but it does represent the long-term monetary interests of management, which is closely tied to the company's market value. As a result, long-term monetary interests can effectively constrain managers' irresponsible behavior (Bouslah et al. [33]). The higher the market 
value of managerial shareholding, the more the managers are motivated to participate in CSR activities. Both the company and the company's manager can get the potential benefits after CSR disclosure. Therefore, we propose Hypothesis 2:

H2. The market value of managerial shareholding has a positive impact on CSR performance.

From the perspective of behavioral economics, some scholars confirm that the managers' fairness perceptions will interfere the efficiency of corporate governance. For example, reasonable incentives for managers can reduce their duty consumption (Xu et al. [59]), and CEOs with lower compensation will pay a higher acquisition premium (Lee et al. [60]). When managers clearly perceive their compensations are higher than others, they may adjust their behavior to meet the obligations beyond what is stipulated in the compensation contract. Therefore, we propose Hypothesis 3 and Hypothesis 4:

H3. When the managerial shareholding ratio is higher than the industry average, CSR performance is relatively higher.

H4. When the market value of managerial shareholding is higher than the industry average, CSR performance is relatively higher.

\subsubsection{Managerial Shareholding and CSR: The Role of Internal Control Quality}

Internal control is penetrated into all processes of the company's operations. It is clearly stipulated in the "Application Guidelines for Company's Internal Control" that companies should pay attention to the risks related to CSR.

It is generally believed that the internal control is an important part of restricting managerial behavior. High internal control quality can promote CSR by reducing agency costs (Li et al. [61]). For its supervisory function, internal control curbs managers' irresponsible self-interested behavior and reduces their opportunism in CSR investment. In addition, internal control has an incentive function that can enhance managers' self-discipline and promote them to create greater value for the company (Dong et al. [62]). Therefore, we propose Hypothesis 5-8:

H5. Internal control quality promotes the positive impact of managerial shareholding ratio on CSR performance.

H6. Internal control quality promotes the positive impact of the market value of managerial shareholding ratio on CSR performance.

H7. Internal control quality promotes the positive impact of the excess managerial shareholding ratio on CSR performance.

H8. Internal control quality promotes the positive impact of the excess marker value of managerial shareholding on CSR performance.

\subsection{Variables and Data Source}

\subsubsection{Dependent Variable}

At present, there are several methods for measuring CSR performance, including content analysis, reputation index and rating index. The content analysis focuses on the content of the CSR report, assigning points for each dimension according to the pre-established standard, such as the frequency of the word "environment protection", the text length of each CSR dimension, the usage of charts and so on. The reputation index is obtained by issuing questionnaires to various stakeholders. The related stakeholders evaluate the companies according to their perception of its CSR performance. The total score is calculated according to a given standard. The reputation index is subjective. The rating index is obtained by a specialized CSR evaluation team, which take both advantages of the content analysis and the reputation index into account. It is objective and comprehensive. 
We use the Rankins CSR Rankings to measure the CSR performance of Chinese listed companies. As a third-party organization, Rankins adopts a three-level evaluation system with 15 first-level indicators and 63 s-level indicators to evaluate the CSR performance of Chinese listed companies, which issue CSR reports. The score is summarized from four dimensions-macrocosm, content, technique and industry. Four dimensions of CSR account for 30\%, $45 \%, 15 \%$ and $10 \%$ of the overall CSR performance respectively, which well reflects the overall CSR performance. Therefore, we use the Rankins CSR Rankings (CSR) as the dependent variable.

\subsubsection{Independent Variables}

In terms of managerial shareholding, we use four variables to measure it. The managerial shareholding ratio (MSR) and the market value of managerial shareholding (MSV) are the ratio and the market value of the shares held by the management team. Management team include directors, supervisors and senior managers. The excess managerial shareholding ratio $\left(e x \_M S R\right)$ is a dummy variable. If the managerial shareholding ratio is higher than the industry average, ex_MSR takes 1 , otherwise, it is 0 . The excess market value of managerial shareholding $\left(e x \_M S V\right)$ is a dummy variable. If the market value of managerial shareholding is higher than the industry average, $e x \_M S V$ takes 1 , otherwise, it is 0 .

As for internal control quality, we use "DIB Internal Control Index of Listed Company in China" (IC) as a proxy to evaluate the effectiveness of internal control of listed company. The index considers the effectiveness of internal control in compliance, reporting, asset security, operation and strategy. The index is objective and reasonable. In recent years, the index has also been widely adopted in academia and practice. Since the value ranges from 0 to 1000, the data used in empirical research is divided by 1000 .

\subsubsection{Control Variables}

Following Che [40], we use overall-level firm characteristics such as profitability, financial leverage, size, age, growth, liquidity and property rights as control variables.

(1) Profitability is proxied by the return on equity $(R O E)$. Shen [63] concluded that only with good earnings could the company afford CSR, and in order to differentiate itself from others with poor financial performance, it also disclosed more CSR information. Therefore, ROE is used as one of the control variables.

(2) Financial leverage (Lev) is measured by the asset-liability ratio. Financial leverage reflects the insolvency risk of listed companies. Therefore, this paper incorporates financial leverage into control variables for research.

(3) The size of the company (Size) takes the natural logarithm of the total assets at the end of the year. Hadley [6] pointed out that the CEOs of large size companies are more political sensitivity and motivated to disclose CSR to obtain their own legality. Meanwhile, the government and the public also have higher expectations of CSR performance for large size companies. Therefore, Size is used as one of the control variables.

(4) Age of listing ( $A g e$ ) is years since its IPO in SZSE or SSE. Reason is that the earlier the company enters into capital market, the higher the public attention paid on its CSR. A mature company pays more importance to its reputation and thus disclose more CSR (Chiu et al. [64]).

(5) Growth is the growth rate of total assets (Growth), which is calculated as the ratio of total asset growth in year $t$ to total assets at the beginning of the year $t$.

(6) Liquidity is measured by Cashflow, which is the proportion of net cash flow generated by operating activities to net profit. 
(7) The property rights $(S O E)$ is determined by the character of the actual controller of the company. We use dummy variables. If the actual controller is a state-owned entity, such as central authority, local governments, and administrative institutions, it is recognized as a state-owned enterprise and assigned value of 1 , otherwise, it is 0 .

The definition of each variable is shown in Table 1.

Table 1. Variable descriptions.

\begin{tabular}{|c|c|c|}
\hline Variable & & Description \\
\hline Dependent variable & CSR & Rankins CSR Rankings \\
\hline \multirow{5}{*}{ Independent variables } & $M S R$ & Managerial shareholding ratio \\
\hline & $M S V$ & The market value of managerial shareholding (in billions) \\
\hline & $e x \_M S R$ & $\begin{array}{l}\text { If managerial shareholding ratio is higher than industry average, } \\
\text { takes } 1 \text {, otherwise } 0\end{array}$ \\
\hline & ex_MSV & $\begin{array}{l}\text { If the market value of managerial shareholding is higher than } \\
\text { industry average, takes } 1 \text {, otherwise } 0\end{array}$ \\
\hline & IC & DIB Internal Control Index divided by 1000 \\
\hline \multirow{9}{*}{ Control variables } & $R O E$ & Return on equity \\
\hline & Lev & Asset-liability ratio \\
\hline & Size & Natural logarithm of total assets \\
\hline & Age & Years since its IPO in SZSE or SSE \\
\hline & Growth & The growth rate of total asset \\
\hline & Cashflow & $\begin{array}{l}\text { The proportion of net cash flow generated by operating activities to } \\
\text { net profit. }\end{array}$ \\
\hline & SOE & State-owned takes 1 , otherwise 0 \\
\hline & Year & Dummy variables \\
\hline & Industry & Dummy variables \\
\hline
\end{tabular}

\subsubsection{Data Source}

This paper takes the data of 2013-2017 A-share listed companies with Rankins CSR Ratings as sample, which are obtained from the Rankins A-share listed company CSR rating database. The internal control quality index comes from "DIB China Listed Company Internal Control Index", which is issued by Shenzhen DIB Risk Management Technology Co., Ltd. Other relevant data come from CSMAR database. These sources are all reliable and authentic.

The initial samples are processed as follows: (1) Excluding finance and insurance companies; (2) excluding ST (* ST) companies, whose stocks price' daily increase or decrease is limited to $5 \%\left({ }^{*} \mathrm{ST}\right.$ companies also face withdrawal risk) because of suffering losses for two (three) consecutive years; (3) excluding companies with missing data for vital variables. Finally, we obtain 2937 company-year observations. In order to reduce the influence of extreme values on the conclusions, we winsorize all variables at the $1 \%$ and $99 \%$ level.

As shown in Table 2, the full sample can be divided into two groups, including mandatory CSR disclosure group and voluntary CSR disclosure group. There are 1696 observations that belongs to mandatory CSR disclosure group, accounting for 57.7\%. A further description of the industry characteristics is shown in Appendix A. The Manufacturing represented the largest portion of the sample, which is about $16.4 \%$.

Table 2. Constitute of company-year observation.

\begin{tabular}{ccc}
\hline Disclosure & Observation & Proportion (\%) \\
\hline Mandatory & 1696 & 57.7 \\
Voluntary & 1241 & 42.3 \\
Total & 2937 & 100 \\
\hline
\end{tabular}




\subsection{Model Specification}

According to our research hypothesis, we estimate the following eight panel data models. Models 1-4 is used to test the impact of managerial shareholding on CSR performance. Models 5-8 is used to test the role of internal control quality in the impact of managerial shareholdings on CSR performance. All models are run in accordance with mandatory CSR disclosure and voluntary CSR disclosure. In addition, we control year and industry effects in the models. The models are constructed as follows:

In order to verify Hypothesis 1, the model is constructed as:

$$
\operatorname{CSR}_{i, t}=\beta_{0}+\beta_{1} \text { MSR }_{i, t}+\beta_{2} \text { Controls }_{i, t}+\varepsilon_{i, t}
$$

In order to verify Hypothesis 2, the model is constructed as:

$$
\operatorname{CSR}_{i, t}=\beta_{0}+\beta_{1} M S V_{i, t}+\beta_{2} \operatorname{Controls}_{i, t}+\varepsilon_{i, t}
$$

In order to verify Hypothesis 3, the model is constructed as:

$$
\operatorname{CSR}_{i, t}=\beta_{0}+\beta_{1} e x \_M S R_{i, t}+\beta_{2} \text { Controls }_{i, t}+\varepsilon_{i, t}
$$

In order to verify Hypothesis 4, the model is constructed as:

$$
\operatorname{CSR}_{i, t}=\beta_{0}+\beta_{1} e x \_M S V_{i, t}+\beta_{2} \text { Controls }_{i, t}+\varepsilon_{i, t}
$$

In order to verify Hypothesis 5, the model is constructed as:

$$
\operatorname{CSR}_{i, t}=\beta_{0}+\beta_{1} I C_{i, t}+\beta_{2} M S R_{i, t}+\beta_{3} I C_{i, t} \times M S R_{i, t}+\beta_{4} \text { Controls }_{i, t}+\varepsilon_{i, t}
$$

In order to verify Hypothesis 6, the model is constructed as:

$$
\operatorname{CSR}_{i, t}=\beta_{0}+\beta_{1} I C_{i, t}+\beta_{2} M S V_{i, t}+\beta_{3} I C_{i, t} \times M S V_{i, t}+\beta_{4} \text { Controls }_{i, t}+\varepsilon_{i, t}
$$

In order to verify Hypothesis 7, the model is constructed as:

$$
\operatorname{CSR}_{i, t}=\beta_{0}+\beta_{1} I C_{i, t}+\beta_{2} e x \_M S R_{i, t}+\beta_{3} I C_{i, t} \times e x \_M S R_{i, t}+\beta_{4} \text { Controls }_{i, t}+\varepsilon_{i, t}
$$

In order to verify Hypothesis 8, the model is constructed as:

$$
C S R_{i, t}=\beta_{0}+\beta_{1} I C_{i, t}+\beta_{2} e x \_M S V_{i, t}+\beta_{3} I C_{i, t} \times e x \_M S V_{i, t}+\beta_{4} \operatorname{Controls}_{i, t}+\varepsilon_{i, t}
$$

where, $\beta_{0}$ is the constant term, $\beta_{i}$ represent coefficients of the independent variables, the cross-terms and control variables in models. CSR is the Rankins CSR Rankings, MSR is the managerial shareholding ratio, MSV stands for the market value of managerial shareholding, ex_MSR is the excess managerial shareholding ratio, ex_MSV means excess market value of managerial shareholding, Controls includes ROE, Lev, Size, Age, Growth, Cashflow and SOE. Variable subscripts $i$ and $t$ represent company and year, respectively. $\varepsilon$ is the random error term.

For the cross-terms, we follow $\mathrm{Li}$ [65] to perform a mean centering treatment. Cross-multiplication after mean centering treatment does not affect the regression results of the model. Moreover, it eliminates the multi-collinearity between variables.

\subsection{Mandatory CSR Disclosure vs. Voluntary CSR Disclosure}

Mandatory CSR disclosure is a regulatory measure with strict norms. Issuing annual CSR reports are the companies' legal obligation. If the companies do not disclose their CSR performance, 
they will be punished by the government. Thus, legitimacy and compliance may be the main drivers of their CSR disclosure. In addition, setting clear disclosure rules helps to restrict the discretion of managers, reduce agency costs and improve corporate transparency. As for voluntary CSR disclosure, CSR performance reflects more inner motivations. Therefore, this paper divides the full sample into mandatory disclosure group and voluntary disclosure group for discussions.

\section{Empirical Results and Discussions}

\subsection{Descriptive Statistics}

Table 3 gives descriptive statistics for all variables. As shown in Table 3, the average CSR is 40.912 with the standard deviation of 11.267. The minimum value and the maximum value of CSR are 22.373 and 76.601 respectively, which indicate that the CSR performances of Chinese A-share listed companies are quite different.

Table 3. Descriptive statistics.

\begin{tabular}{llllll}
\hline Variable & Obs & Mean & Std. Dev. & Min & Max \\
\hline CSR & 2937 & 40.912 & 11.267 & 22.373 & 76.601 \\
MSR & 2937 & 0.055 & 0.130 & 0.000 & 0.581 \\
MSV & 2937 & 0.842 & 2.574 & 0.000 & 16.581 \\
ex_MSR & 2937 & 0.185 & 0.388 & 0 & 1 \\
ex_MSV & 2937 & 0.141 & 0.348 & 0 & 1 \\
IC & 2937 & 0.670 & 0.078 & 0.339 & 0.843 \\
Size & 2937 & 23.260 & 1.419 & 20.523 & 27.170 \\
ROE & 2937 & 0.082 & 0.093 & -0.335 & 0.332 \\
Lev & 2937 & 0.489 & 0.201 & 0.072 & 0.885 \\
Age & 2937 & 12.863 & 6.151 & 1 & 24 \\
Growth & 2937 & 0.155 & 0.242 & -0.184 & 1.435 \\
Cashflow & 2937 & 1.877 & 5.174 & -13.859 & 32.341 \\
SOE & 2937 & 0.610 & 0.488 & 0 & 1 \\
\hline
\end{tabular}

In terms of managerial shareholding, the average MSR is 0.055 with the standard deviation of 0.130 . The minimum value and the maximum value of $M S R$ are 0 and 0.581 respectively, which indicate that the difference of the managerial shareholding ratio between companies are large. The average MSV is 0.842 , with the standard deviation of 2.574 . The minimum value and the maximum value of $M S V$ are 0 and 16.581 respectively, showing that the differences of the market value of managerial shareholding are great. The average ex_MSR is 0.185 , indicating that only $18.5 \%$ of observations have a higher managerial shareholding ratio than its industry average. The average $e x_{-} M S V$ is 0.141 , indicating that only $14.1 \%$ of observations have a higher market value of managerial shares than its industry average.

As for internal control, the average IC is 0.670 , with the standard deviation of 0.078 . The minimum value and the maximum value of IC are 0.339 and 0.843 respectively, showing that there are great differences in internal control.

Regarding control variables, the average Size is 23.260, with the standard deviation of 1.419 . The minimum value and the maximum value of Size are 20.523 and 27.170 respectively. The average $R O E$ is 0.082 , with the standard deviation of 0.093 . The minimum value and the maximum value of $R O E$ are -0.335 and 0.332 respectively. The average $L e v$ is 0.489 , with the standard deviation of 0.201 . The minimum value and the maximum value of $L e v$ are 0.072 and 0.885 respectively, which indicates that listed companies are generally conservative in debt financing. The average Age is 12.863 , with the standard deviation of 6.151. The minimum value and the maximum value of Age are 1 and 24 respectively, indicating that the listed companies have a longer listing period, that is, companies choose to disclose CSR often enter the capital market earlier. The average Growth is 0.155 , with the standard deviation of 0.242 . The minimum value and the maximum value of Growth are -0.183 and 1.435 respectively, which indicates that Chinese companies are generally experiencing optimistic 
development. The average Cashflow is 1.877 , with the standard deviation of 0.242 . The minimum value and the maximum value of Cashflow are -13.859 and 32.341 respectively, which shows that the cash flow is quite different. The average $S O E$ is 0.610 , indicating that $61.0 \%$ of observations are state-owned enterprises, which is in line with the actual situation.

\subsection{Correlation Analysis}

In order to preliminarily verify the relationship between managerial shareholding and CSR performance, this paper analyzes the correlation coefficient of main variables. The results are shown in Tables 4 and 5 according to different types of disclosure behavior.

Table 4. Correlation matrix: mandatory CSR disclosure group.

\begin{tabular}{|c|c|c|c|c|c|c|}
\hline & CSR & MSR & $M S V$ & ex_MSR & ex_MSV & IC \\
\hline MSR & $-0.050^{* *}$ & 1 & & & & \\
\hline$M S V$ & 0.000 & $0.900^{* * *}$ & 1 & & & \\
\hline$e x \_M S R$ & $-0.043^{*}$ & $0.738^{* * *}$ & $0.670^{* * *}$ & 1 & & \\
\hline$e x \_M S V$ & 0.004 & $0.713^{* * *}$ & $0.728^{* * *}$ & $0.794^{* * *}$ & 1 & \\
\hline IC & $0.216^{* * *}$ & -0.023 & 0.021 & $-0.049^{* *}$ & 0.010 & 1 \\
\hline Size & $0.529^{* * *}$ & $-0.057^{* *}$ & 0.014 & $-0.090^{* * *}$ & 0.017 & $0.332^{* * *}$ \\
\hline$R O E$ & $0.058^{* *}$ & $0.129^{* * *}$ & $0.166^{* * *}$ & $0.117^{* * *}$ & $0.174^{* * *}$ & $0.442^{* * *}$ \\
\hline Lev & $0.164^{* * *}$ & $-0.086^{* * *}$ & $-0.069^{* * *}$ & $-0.085^{* * *}$ & $-0.063^{* * *}$ & $0.075^{* * *}$ \\
\hline Age & $-0.043 *$ & $-0.299 * * *$ & $-0.294^{* * *}$ & $-0.255^{* * *}$ & $-0.255^{* * *}$ & 0.022 \\
\hline Growth & 0.012 & $0.190^{* * *}$ & $0.216^{* * *}$ & $0.167^{* * *}$ & $0.191^{* * *}$ & $0.116^{* * *}$ \\
\hline Cashflow & $0.089^{* * *}$ & $-0.043 *$ & $-0.041 *$ & -0.043 * & -0.032 & 0.001 \\
\hline \multirow[t]{2}{*}{$S O E$} & $0.171^{* * *}$ & $-0.406^{* * *}$ & $-0.348^{* * *}$ & $-0.391^{* * *}$ & $-0.408^{* * *}$ & $0.047^{*}$ \\
\hline & Size & $R O E$ & Lev & Age & Growth & Cashflow \\
\hline$R O E$ & $0.100^{* * *}$ & 1 & & & & \\
\hline Lev & $0.502^{* * *}$ & $-0.170^{* * *}$ & 1 & & & \\
\hline Age & $-0.076^{* * *}$ & $-0.052^{* *}$ & 0.039 & 1 & & \\
\hline Growth & $0.052 * *$ & $0.262 * * *$ & 0.041 * & $-0.117^{* * *}$ & 1 & \\
\hline Cashflow & $0.092^{* * *}$ & $-0.137^{* * *}$ & $0.097^{* * *}$ & -0.009 & $-0.158^{* * *}$ & 1 \\
\hline$S O E$ & $0.176^{* * *}$ & $-0.146^{* * *}$ & $0.104^{* * *}$ & $0.137^{* * *}$ & $-0.131^{* * *}$ & $0.064^{* * *}$ \\
\hline
\end{tabular}

Note: ${ }^{* * *}$ denotes statistical significance at the $1 \%$ level. ${ }^{* *}$ denotes statistical significance at the $5 \%$ level. ${ }^{*}$ denotes statistical significance at the $10 \%$ level.

Table 5. Correlation matrix: voluntary CSR disclosure group.

\begin{tabular}{|c|c|c|c|c|c|c|}
\hline & CSR & $M S R$ & $M S V$ & $e x \_M S R$ & $e x \_M S V$ & IC \\
\hline MSR & $-0.071^{* *}$ & 1 & & & & \\
\hline$M S V$ & $0.058^{* *}$ & $0.707^{* * *}$ & 1 & & & \\
\hline ex_MSR & -0.010 & $0.845^{* * *}$ & $0.620^{* * *}$ & 1 & & \\
\hline ex_MSV & 0.034 & $0.749^{* * *}$ & $0.702^{* * *}$ & $0.760 * * *$ & 1 & \\
\hline IC & $0.084^{* * *}$ & 0.026 & 0.044 & 0.041 & 0.035 & 1 \\
\hline Size & $0.271^{* * *}$ & $-0.334^{* * *}$ & $-0.063^{* *}$ & $-0.276^{* * *}$ & $-0.143^{* * *}$ & 0.046 \\
\hline$R O E$ & $0.067^{* *}$ & $0.142^{* * *}$ & $0.240^{* * *}$ & $0.143^{* * *}$ & $0.190 * * *$ & $0.365^{* * *}$ \\
\hline Lev & $0.105^{* * *}$ & $-0.272^{* * *}$ & $-0.154^{* * *}$ & $-0.231^{* * *}$ & $-0.175^{* * *}$ & $-0.057^{* *}$ \\
\hline Age & $0.109^{* * *}$ & $-0.508^{* * *}$ & $-0.326^{* * *}$ & $-0.467^{* * *}$ & $-0.381^{* * *}$ & $-0.049 *$ \\
\hline Growth & -0.001 & $0.184^{* * *}$ & $0.262^{* * *}$ & $0.174^{* * *}$ & $0.212^{* * *}$ & $0.134^{* * *}$ \\
\hline Cashflow & 0.018 & $-0.093^{* * *}$ & $-0.065^{* *}$ & $-0.104^{* * *}$ & $-0.060 * *$ & 0.003 \\
\hline \multirow[t]{2}{*}{$S O E$} & $0.151^{* * *}$ & $-0.507^{* * *}$ & $-0.375^{* * *}$ & $-0.548^{* * *}$ & $-0.451^{* * *}$ & -0.009 \\
\hline & Size & $R O E$ & Lev & Age & Growth & Cashflow \\
\hline$R O E$ & 0.025 & 1 & & & & \\
\hline Lev & $0.610^{* * *}$ & $-0.192 * * *$ & 1 & & & \\
\hline Age & $0.382^{* * *}$ & $-0.133^{* * *}$ & $0.322^{* * *}$ & 1 & & \\
\hline Growth & $0.105^{* * *}$ & $0.249^{* * *}$ & 0.030 & $-0.112 * * *$ & 1 & \\
\hline Cashflow & $0.094^{* * *}$ & $-0.073^{* *}$ & $0.068^{* *}$ & $0.069 * *$ & $-0.124^{* * *}$ & 1 \\
\hline$S O E$ & $0.259 * * *$ & $-0.173^{* * *}$ & $0.256^{* * *}$ & $0.409^{* * *}$ & $-0.172^{* * *}$ & $0.133^{* * *}$ \\
\hline
\end{tabular}

Note: ${ }^{* * *}$ denotes statistical significance at the $1 \%$ level. ${ }^{* *}$ denotes statistical significance at the $5 \%$ level. ${ }^{*}$ denotes statistical significance at the $10 \%$ level. 
As for mandatory disclosure group, MSR and $e x \_M S R$ are significantly negative correlated to $C S R$, indicating that the managerial shareholding ratio and the excess managerial shareholding ratio have negative impact on the quality of CSR performance, which initially reject Hypotheses $\mathrm{H} 1$ and $\mathrm{H} 3$. The relationship between $M S V$, ex_MSV and CSR is not significant.

As for voluntary disclosure group, MSR and MSV are significantly correlated with CSR, while $e x \_M S R$ and $e x \_M S V$ have no significant correlations with CSR. Such results reject Hypotheses $\mathrm{H} 3$ and $\mathrm{H} 4$, but preliminarily verify Hypotheses $\mathrm{H} 1$ and $\mathrm{H} 2$.

According to Tables 4 and 5, MSR, MSV, ex_MSR and $e x \_M S V$ are highly correlated. As a result, these four variables need to be brought into the model separately. The correlation coefficients between the remaining variables are all less than 0.7 , with the minimum value of -0.548 and the maximum value of 0.610 . There is no severe multicollinearity.

\subsection{Regression Analysis}

It is necessary to judge whether to use fixed effect model, or random effect model. The results of Hausman test show that the fixed effect model is better than the random effect model. As a result, we estimate the panel data models with fixed effect. The regression results are shown in Tables 6 and 7 .

Table 6. Managerial shareholding and CSR.

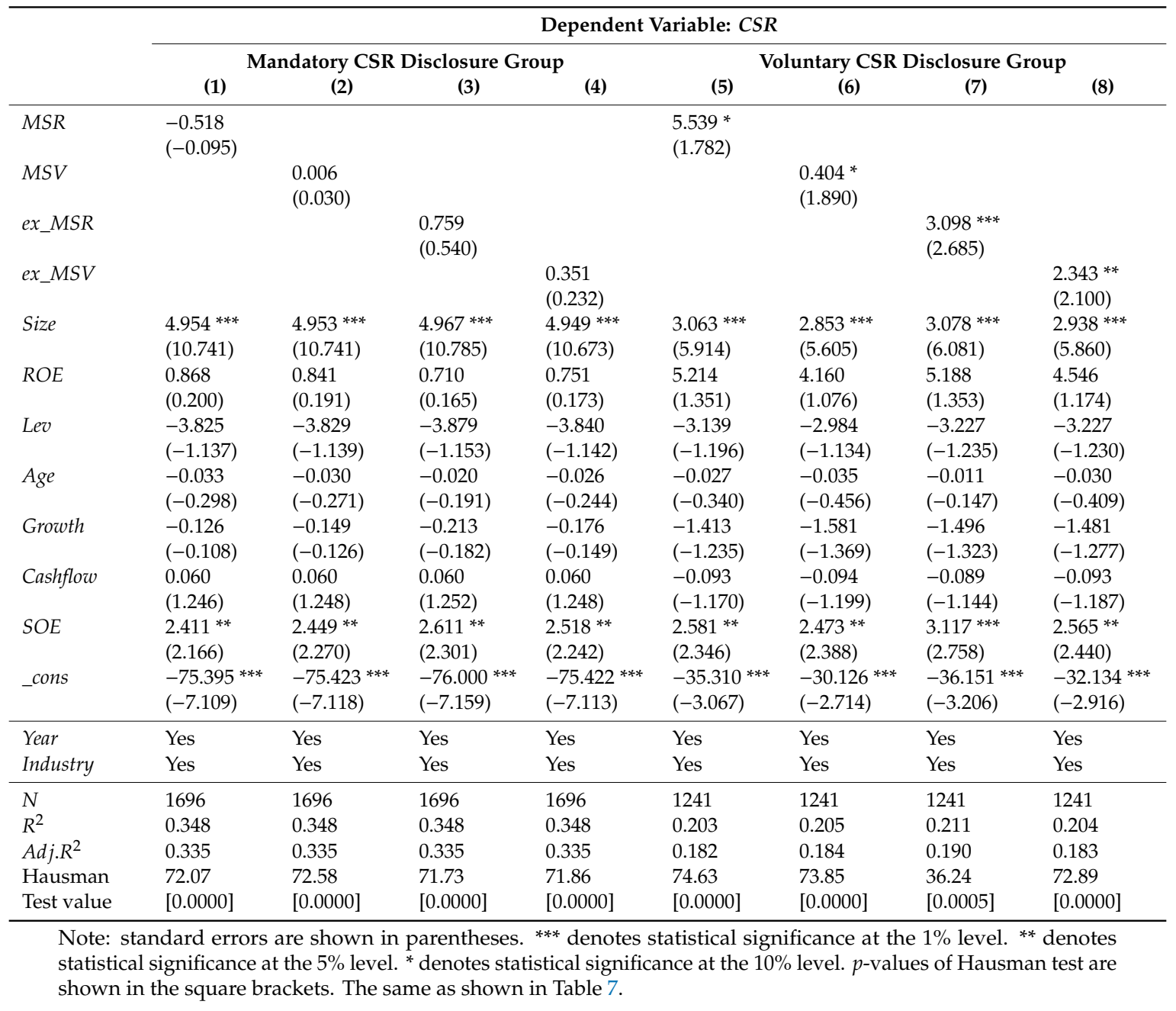

Table 6 shows the regression results of Models 1-4, to test the impact of managerial shareholding on CSR performance. In mandatory CSR disclosure group, the coefficients of the four variables (MSR, MSV, ex_MSR, and $e x \_M S V$ ) are not significant, which indicate that managerial shareholding and excessive 
managerial shareholding have no significant impact on CSR. When the listed company is mandated by the government to disclosure its CSR performance, the administrative pressure loosens the ties between the managerial shareholding and CSR performance. However, in voluntary CSR disclosure group, the coefficients of the four variables (MSR, MSV, ex_MSR, and $\left.e x \_M S V\right)$ are significantly positive, which indicate that managerial shareholding and excessive managerial shareholding have significantly positive impact on CSR. Hypotheses H1-4 are supported. There are obvious differences between these two groups.

Table 7. The role of internal control quality.

\begin{tabular}{|c|c|c|c|c|c|c|c|c|}
\hline & \multicolumn{8}{|c|}{ Dependent Variable: $C S R$} \\
\hline & \multicolumn{4}{|c|}{ Mandatory CSR Disclosure Group } & \multicolumn{4}{|c|}{ Voluntary CSR Disclosure Group } \\
\hline & (1) & (2) & (3) & (4) & (5) & (6) & (7) & (8) \\
\hline IC & $\begin{array}{l}10.349^{* *} \\
(2.159)\end{array}$ & $\begin{array}{l}9.752 * * \\
(2.016)\end{array}$ & $\begin{array}{l}11.244^{* *} \\
(2.317)\end{array}$ & $\begin{array}{l}10.548^{* *} \\
(2.171)\end{array}$ & $\begin{array}{l}7.236 \\
(1.565)\end{array}$ & $\begin{array}{l}8.375^{*} \\
(1.881)\end{array}$ & $\begin{array}{l}6.743 \\
(1.498)\end{array}$ & $\begin{array}{l}7.738^{*} \\
(1.720)\end{array}$ \\
\hline MSR & $\begin{array}{l}-0.176 \\
(-0.033)\end{array}$ & & & & $\begin{array}{l}6.268^{* *} \\
(1.970)\end{array}$ & & & \\
\hline$M S R \times I C$ & $\begin{array}{l}16.210 \\
(0.406)\end{array}$ & & & & $\begin{array}{l}45.050 * * \\
(2.517)\end{array}$ & & & \\
\hline MSV & & $\begin{array}{l}0.021 \\
(0.100)\end{array}$ & & & & $\begin{array}{l}0.431^{* *} \\
(2.061)\end{array}$ & & \\
\hline$M S V \times I C$ & & $\begin{array}{l}-0.167 \\
(-0.137)\end{array}$ & & & & $\begin{array}{l}3.486^{* * *} \\
(3.146)\end{array}$ & & \\
\hline ex_MSR & & & $\begin{array}{l}0.886 \\
(0.641)\end{array}$ & & & & $\begin{array}{l}3.356^{* * *} \\
(2.868)\end{array}$ & \\
\hline$e x \_M S R \times I C$ & & & $\begin{array}{l}12.166 \\
(0.940)\end{array}$ & & & & $\begin{array}{l}22.505^{* * *} \\
(2.896)\end{array}$ & \\
\hline ex_MSV & & & & $\begin{array}{l}0.229 \\
(0.156)\end{array}$ & & & & $\begin{array}{l}2.679 * * \\
(2.359)\end{array}$ \\
\hline$e x \_M S V \times I C$ & & & & $\begin{array}{l}15.738 \\
(1.361)\end{array}$ & & & & $\begin{array}{l}24.419^{* * *} \\
(3.006)\end{array}$ \\
\hline Size & $\begin{array}{l}4.779 * * * \\
(10.505)\end{array}$ & $\begin{array}{l}4.770 * * * \\
(10.500)\end{array}$ & $\begin{array}{l}4.797^{* * *} \\
(10.561)\end{array}$ & $\begin{array}{l}4.785^{* * *} \\
(10.471)\end{array}$ & $\begin{array}{l}3.074^{* * *} \\
(5.933)\end{array}$ & $\begin{array}{l}2.866^{* * *} \\
(5.633)\end{array}$ & $\begin{array}{l}3.068^{* * *} \\
(6.095)\end{array}$ & $\begin{array}{l}2.917^{* * *} \\
(5.860)\end{array}$ \\
\hline$R O E$ & $\begin{array}{l}-2.951 \\
(-0.639)\end{array}$ & $\begin{array}{l}-2.984 \\
(-0.637)\end{array}$ & $\begin{array}{l}-3.031 \\
(-0.656)\end{array}$ & $\begin{array}{l}-2.919 \\
(-0.626)\end{array}$ & $\begin{array}{l}2.825 \\
(0.704)\end{array}$ & $\begin{array}{l}1.292 \\
(0.322)\end{array}$ & $\begin{array}{l}2.763 \\
(0.694)\end{array}$ & $\begin{array}{l}2.023 \\
(0.503)\end{array}$ \\
\hline Lev & $\begin{array}{l}-3.717 \\
(-1.103)\end{array}$ & $\begin{array}{l}-3.717 \\
(-1.103)\end{array}$ & $\begin{array}{l}-3.752 \\
(-1.113)\end{array}$ & $\begin{array}{l}-3.801 \\
(-1.131)\end{array}$ & $\begin{array}{l}-3.129 \\
(-1.196)\end{array}$ & $\begin{array}{l}-3.168 \\
(-1.207)\end{array}$ & $\begin{array}{l}-3.183 \\
(-1.221)\end{array}$ & $\begin{array}{l}-3.210 \\
(-1.226)\end{array}$ \\
\hline Age & $\begin{array}{l}-0.041 \\
(-0.380)\end{array}$ & $\begin{array}{l}-0.040 \\
(-0.363)\end{array}$ & $\begin{array}{l}-0.026 \\
(-0.252)\end{array}$ & $\begin{array}{l}-0.032 \\
(-0.301)\end{array}$ & $\begin{array}{l}-0.030 \\
(-0.374)\end{array}$ & $\begin{array}{l}-0.040 \\
(-0.519)\end{array}$ & $\begin{array}{l}-0.014 \\
(-0.184)\end{array}$ & $\begin{array}{l}-0.031 \\
(-0.418)\end{array}$ \\
\hline Growth & $\begin{array}{l}-0.198 \\
(-0.170)\end{array}$ & $\begin{array}{l}-0.203 \\
(-0.173)\end{array}$ & $\begin{array}{l}-0.320 \\
(-0.273)\end{array}$ & $\begin{array}{l}-0.245 \\
(-0.209)\end{array}$ & $\begin{array}{l}-1.653 \\
(-1.451)\end{array}$ & $\begin{array}{l}-1.847 \\
(-1.612)\end{array}$ & $\begin{array}{l}-1.672 \\
(-1.487)\end{array}$ & $\begin{array}{l}-1.696 \\
(-1.463)\end{array}$ \\
\hline Cashflow & $\begin{array}{l}0.057 \\
(1.172)\end{array}$ & $\begin{array}{l}0.057 \\
(1.171)\end{array}$ & $\begin{array}{l}0.056 \\
(1.162)\end{array}$ & $\begin{array}{l}0.057 \\
(1.173)\end{array}$ & $\begin{array}{l}-0.096 \\
(-1.216)\end{array}$ & $\begin{array}{l}-0.097 \\
(-1.262)\end{array}$ & $\begin{array}{l}-0.091 \\
(-1.166)\end{array}$ & $\begin{array}{l}-0.092 \\
(-1.183)\end{array}$ \\
\hline$S O E$ & $\begin{array}{l}2.317^{* *} \\
(2.073)\end{array}$ & $\begin{array}{l}2.362^{* *} \\
(2.179)\end{array}$ & $\begin{array}{l}2.511^{* *} \\
(2.206)\end{array}$ & $\begin{array}{l}2.388^{* *} \\
(2.118)\end{array}$ & $\begin{array}{l}2.517^{* *} \\
(2.286)\end{array}$ & $\begin{array}{l}2.379^{* *} \\
(2.301)\end{array}$ & $\begin{array}{l}3.024^{* * *} \\
(2.681)\end{array}$ & $\begin{array}{l}2.505^{* *} \\
(2.391)\end{array}$ \\
\hline _cons & $\begin{array}{l}-77.892 * * * \\
(-7.227)\end{array}$ & $\begin{array}{l}-77.323^{* * * *} \\
(-7.195)\end{array}$ & $\begin{array}{l}-79.295^{* * *} \\
(-7.352)\end{array}$ & $\begin{array}{l}-78.304 \\
(-7.297)\end{array}$ & $\begin{array}{l}-40.4411^{* * *} \\
(-3.437)\end{array}$ & $\begin{array}{l}-35.908^{* * * *} \\
(-3.160)\end{array}$ & $\begin{array}{l}-40.5411^{* * * *} \\
(-3.551)\end{array}$ & $\begin{array}{l}-36.925^{* * *} \\
(-3.297)\end{array}$ \\
\hline Year & Yes & Yes & Yes & Yes & Yes & Yes & Yes & Yes \\
\hline Industry & Yes & Yes & Yes & Yes & Yes & Yes & Yes & Yes \\
\hline$N$ & 1696 & 1696 & 1696 & 1696 & 1241 & 1241 & 1241 & 1241 \\
\hline$R^{2}$ & 0.351 & 0.351 & 0.351 & 0.351 & 0.210 & 0.214 & 0.220 & 0.213 \\
\hline Adj. $R^{2}$ & 0.337 & 0.337 & 0.338 & 0.338 & 0.187 & 0.192 & 0.198 & 0.191 \\
\hline Hausman & 74.99 & 44.65 & 75.72 & 51.24 & 59.70 & 108.75 & 34.66 & 67.25 \\
\hline Test Value & 0.0000 & 0.0001 & 0.0000 & 0.0000 & 0.0000 & 0.0000 & 0.0027 & 0.0000 \\
\hline
\end{tabular}

The results of the role of internal control quality in the impact of managerial shareholding on CSR performance are presented in Table 7. In mandatory CSR disclosure group, the coefficients of the four cross-terms $\left(M S R \times I C, M S V \times I C, e x \_M S R \times I C\right.$, and $\left.e x \_M S V \times I C\right)$ are not significant. It indicates that internal control quality has no significant role in the impact of managerial shareholding on CSR performance, although internal control quality itself plays a significantly positive role in promoting CSR performance in mandatory disclosure group. When the listed company is mandated by the government to disclosure its CSR performance, internal control quality plays no role in the impact of managerial 
shareholding on CSR performance. However, in voluntary CSR disclosure group, the coefficients of the four cross-terms $\left(M S R \times I C, M S V \times I C, e x \_M S R \times I C\right.$, and $\left.e x \_M S V \times I C\right)$ are significantly positive. The internal control quality plays a significantly positive role in the impact of managerial shareholding on CSR performance. Hypotheses H5-8 are supported. It indicates that in the listed companies that voluntarily disclose CSR, efficient internal control can promote the positive effect of managerial shareholding on CSR performance.

\subsection{Robust Test}

In order to test the robustness of the regression results, we do two Robust tests. In robust test 1, we use CSR_mct to replace CSR as the dependent variable in the panel data models. CSR_mct is equal to CSR minus the industry scores. Since we control for the industry in the regression model, this method is reasonable. The regression results of robust test 1 are shown in Appendix B. The findings of robust test 1 are consistent with the findings in Tables 6 and 7.

Moreover, our benchmark empirical models do not consider corporate governance determinations like board characteristics, etc. There is evidence that board size (Said et al. [66]), the proportion of independent directors (Harjoto et al. [67]), CEO duality (Garcia-Torea et al. [68]) and the institutional shareholding ratio (Lopez-Iturriaga et al. [69]) have significant effect on CSR performance. We add these control variables in the panel data models in robust test 2. Board size (Boardsize) is reflected by the number of board members. The proportion of independent directors (Indep) is the ratio of the number of independent directors to the number of board members. The variable proxy CEO duality (Dual), takes 1 when the chairman is the same person as the CEO, otherwise, it is 0 . The institutional shareholding ratio (Insti) is the sum of the shareholding ratio of funds, qualified foreign investors, dealers, insurance, social security funds, trusts, financial companies, banks, and non-financial listed companies. The regression results of robust test 2 are shown in Appendix B. The findings of robust test 2 are consistent with the findings in Tables 6 and 7.

\section{Conclusions and Policy Implications}

\subsection{Conclusions}

This paper uses the data of Rankins CSR Rankings of A-share listed companies from 2013-2017 as the sample. By dividing the sample into mandatory disclosure group and voluntary disclosure group, we first empirically test the impacts of managerial shareholding on CSR performance. Then, we discuss the role of internal control quality in the impacts of managerial shareholding on CSR performance.

In mandatory CSR disclosure group, both the managerial shareholding and the excessive managerial shareholding have no significant impacts on CSR performance. However, in voluntary CSR disclosure group, both the managerial shareholding and the excessive managerial shareholding have significantly positive impacts on CSR performance. It means that the administrative pressure may hamper the positive impact of managerial shareholding on CSR performance. Our findings are consistent with the previous findings in the literature that managerial shareholding has a gross effect on CSR performance (Li et al. [35]). The most important influencing factors on CSR performance are the ratio of managerial shareholding and the excessive ratio of managerial shareholding.

We find evidence that internal control quality plays no role in the impacts of managerial shareholding on CSR performance in mandatory disclosure group. However, in voluntary disclosure group, internal control quality plays a significant role in promoting the positive impact of managerial shareholding on CSR performance.

\subsection{Policy Implications}

With the aim of promoting listed companies to actively improve their CSR performance, this paper proposes the following policy recommendations: 
Firstly, we should strengthen the CSR awareness of listed companies. In terms of managers, they should take social responsibility as their own duty, and integrate social responsibility into the cultural construction of companies. In the social aspect, public opinion counts. Judging from the irresponsible social behavior, the intervention of the media has amplified the economic consequences of lacking in CSR, which gives warning to the companies. As for government supervision, it is necessary to give an official guidelines of CSR performance to the involved companies, as well as establish a reward and punishment system.

Secondly, we should improve the internal control quality of listed company. Listed company should learn to balance the interests of all stakeholders. When evaluating the value of the company, criteria should be expanded from economic profits to the value created for employees, customers, governments, etc. For improving CSR performance, it would be a good choice for the companies to implement long-term equity incentives. Companies should ensure that the internal controls related to CSR performance can be operated effectively. In addition, companies should give full play to internal control in promoting CSR performance.

In this paper, we focus on the managerial shareholding to draw conclusions about the drivers of CSR performance. Our research could be further improved by providing more precise measurement of the market value of managerial shareholding. In addition, we only study on whether the excess managerial shareholding ratio and the excess market value of managerial shareholding have impacts on CSR performance in voluntary disclosure group. In the future, we will study on the impacts of the extent to which the managerial shareholding ratio and market value of managerial shareholding is higher than industry level on CSR performance.

Author Contributions: Concept, Methodology and Supervision, Writing Review \& Editing, M.G.; Data curation, Formal analysis, Investigation, Resources, Software and Validation, Visualization, Writing-Original Draft, S.S.

Funding: This research was funded by [Independent Innovation Fund of Tianjin University] grant number [2019XSC-0032] and [Soft Science Research Program of Tianjin Science and Technology Commission] grant number [18ZLZXZF00500].

Conflicts of Interest: The authors declare no conflicts of interest.

\section{Appendix A}

Table A1. The structure of the sample companies by industry.

\begin{tabular}{lcc}
\hline \multicolumn{1}{c}{ Industry } & Observation & Proportion (\%) \\
\hline Mining & 141 & 4.8 \\
Communication and Cultural Industry & 68 & 2.3 \\
Utilities & 155 & 5.3 \\
Electronics & 103 & 3.5 \\
Real estate & 197 & 6.7 \\
Textiles \& Apparel & 83 & 2.8 \\
Machinery & 483 & 16.4 \\
Construction & 114 & 3.9 \\
Transportation & 163 & 5.5 \\
Metals \& Non-metals & 270 & 9.2 \\
Timber \& Furnishings & 2 & 0.1 \\
Agriculture, forestry, livestock farming, fishery & 39 & 1.3 \\
Wholesale and retail trade & 155 & 5.3 \\
Other manufacturing & 16 & 0.5 \\
Social Services & 69 & 2.3 \\
Petrochemicals & 224 & 7.6 \\
Food \& Beverage & 150 & 5.1 \\
IT & 245 & 8.3 \\
Pharmaceuticals & 159 & 5.4 \\
Paper \& Printing & 49 & 1.7 \\
Comprehensive & 54 & 1.8 \\
Total & 2937 & 100 \\
\hline
\end{tabular}




\section{Appendix B}

The regression results of robust tests

Table A2. Robust test 1 -Managerial shareholding and CSR.

\begin{tabular}{|c|c|c|c|c|c|c|c|c|}
\hline & \multicolumn{8}{|c|}{ Dependent Variable: $C S R \_m c t$} \\
\hline & \multicolumn{4}{|c|}{ Mandatory CSR Disclosure Group } & \multicolumn{4}{|c|}{ Voluntary CSR Disclosure Group } \\
\hline & (1) & (2) & (3) & (4) & (5) & (6) & (7) & (8) \\
\hline$M S R$ & $\begin{array}{l}-0.021 \\
(-0.004)\end{array}$ & & & & $\begin{array}{l}5.005 * \\
(1.741)\end{array}$ & & & \\
\hline$M S V$ & & $\begin{array}{l}0.004 \\
(0.024)\end{array}$ & & & & $\begin{array}{l}0.361 * \\
(1.835)\end{array}$ & & \\
\hline ex_MSR & & & $\begin{array}{l}0.763 \\
(0.598)\end{array}$ & & & & $\begin{array}{l}2.870 * * * \\
(2.703)\end{array}$ & \\
\hline ex_MSV & & & & $\begin{array}{l}0.366 \\
(0.267)\end{array}$ & & & & $\begin{array}{l}2.181 * * \\
(2.121)\end{array}$ \\
\hline Size & $\begin{array}{l}4.480 \text { *** } \\
(10.879)\end{array}$ & $\begin{array}{l}4.479 * * * \\
(10.863)\end{array}$ & $\begin{array}{l}4.493^{* * *} \\
(10.937)\end{array}$ & $\begin{array}{l}4.475^{* * *} \\
(10.803)\end{array}$ & $\begin{array}{l}2.769 * * * \\
(5.711)\end{array}$ & $\begin{array}{l}2.580 * * * \\
(5.402)\end{array}$ & $\begin{array}{l}2.785^{* * *} \\
(5.872)\end{array}$ & $\begin{array}{l}2.655^{* * *} \\
(5.651)\end{array}$ \\
\hline$R O E$ & $\begin{array}{l}1.017 \\
(0.257)\end{array}$ & $\begin{array}{l}1.007 \\
(0.251)\end{array}$ & $\begin{array}{l}0.872 \\
(0.221)\end{array}$ & $\begin{array}{l}0.910 \\
(0.229)\end{array}$ & $\begin{array}{l}4.784 \\
(1.355)\end{array}$ & $\begin{array}{l}3.843 \\
(1.089)\end{array}$ & $\begin{array}{l}4.757 \\
(1.357)\end{array}$ & $\begin{array}{l}4.158 \\
(1.176)\end{array}$ \\
\hline Lev & $\begin{array}{l}-3.605 \\
(-1.169)\end{array}$ & $\begin{array}{l}-3.606 \\
(-1.169)\end{array}$ & $\begin{array}{l}-3.657 \\
(-1.186)\end{array}$ & $\begin{array}{l}-3.618 \\
(-1.173)\end{array}$ & $\begin{array}{l}-3.152 \\
(-1.299)\end{array}$ & $\begin{array}{l}-3.016 \\
(-1.238)\end{array}$ & $\begin{array}{l}-3.229 \\
(-1.336)\end{array}$ & $\begin{array}{l}-3.228 \\
(-1.330)\end{array}$ \\
\hline Age & $\begin{array}{l}-0.043 \\
(-0.430)\end{array}$ & $\begin{array}{l}-0.042 \\
(-0.424)\end{array}$ & $\begin{array}{l}-0.033 \\
(-0.336)\end{array}$ & $\begin{array}{l}-0.038 \\
(-0.393)\end{array}$ & $\begin{array}{l}-0.023 \\
(-0.320)\end{array}$ & $\begin{array}{l}-0.031 \\
(-0.438)\end{array}$ & $\begin{array}{l}-0.008 \\
(-0.111)\end{array}$ & $\begin{array}{l}-0.025 \\
(-0.373)\end{array}$ \\
\hline Growth & $\begin{array}{l}-0.062 \\
(-0.058)\end{array}$ & $\begin{array}{l}-0.068 \\
(-0.063)\end{array}$ & $\begin{array}{l}-0.134 \\
(-0.126)\end{array}$ & $\begin{array}{l}-0.099 \\
(-0.091)\end{array}$ & $\begin{array}{l}-1.205 \\
(-1.166)\end{array}$ & $\begin{array}{l}-1.352 \\
(-1.297)\end{array}$ & $\begin{array}{l}-1.290 \\
(-1.264)\end{array}$ & $\begin{array}{l}-1.278 \\
(-1.218)\end{array}$ \\
\hline Cashflow & $\begin{array}{l}0.048 \\
(1.149)\end{array}$ & $\begin{array}{l}0.048 \\
(1.149)\end{array}$ & $\begin{array}{l}0.049 \\
(1.154)\end{array}$ & $\begin{array}{l}0.048 \\
(1.149)\end{array}$ & $\begin{array}{l}-0.085 \\
(-1.206)\end{array}$ & $\begin{array}{l}-0.086 \\
(-1.235)\end{array}$ & $\begin{array}{l}-0.082 \\
(-1.181)\end{array}$ & $\begin{array}{l}-0.085 \\
(-1.225)\end{array}$ \\
\hline$S O E$ & $\begin{array}{l}2.189 * * \\
(2.143)\end{array}$ & $\begin{array}{l}2.196^{* *} \\
(2.215)\end{array}$ & $\begin{array}{l}2.363^{* *} \\
(2.270)\end{array}$ & $\begin{array}{l}2.272 * * \\
(2.204)\end{array}$ & $\begin{array}{l}2.297 * * \\
(2.258)\end{array}$ & $\begin{array}{l}2.194 * * \\
(2.291)\end{array}$ & $\begin{array}{l}2.808^{* * *} \\
(2.688)\end{array}$ & $\begin{array}{l}2.299 * * \\
(2.367)\end{array}$ \\
\hline _cons & $\begin{array}{l}-66.222^{* * *} \\
(-7.009)\end{array}$ & $\begin{array}{l}-66.218^{* * *} \\
(-7.008)\end{array}$ & $\begin{array}{l}-66.795^{* * *} \\
(-7.068)\end{array}$ & $\begin{array}{l}-66.214^{* * *} \\
(-7.006)\end{array}$ & $\begin{array}{l}-29.910^{* * *} \\
(-2.783)\end{array}$ & $\begin{array}{l}-25.241 \\
(-2.430)\end{array}$ & $\begin{array}{l}-30.776^{* * *} \\
(-2.920)\end{array}$ & $\begin{array}{l}-27.057 \\
(-2.626)\end{array}$ \\
\hline Year & Yes & Yes & Yes & Yes & Yes & Yes & Yes & Yes \\
\hline Industry & Yes & Yes & Yes & Yes & Yes & Yes & Yes & Yes \\
\hline$N$ & 1696 & 1696 & 1696 & 1696 & 1241 & 1241 & 1241 & 1241 \\
\hline$R^{2}$ & 0.338 & 0.338 & 0.338 & 0.338 & 0.198 & 0.201 & 0.207 & 0.200 \\
\hline Adj. $R^{2}$ & 0.325 & 0.325 & 0.326 & 0.325 & 0.177 & 0.180 & 0.186 & 0.179 \\
\hline
\end{tabular}

Table A3. Robust test 1 -The role of internal control quality.

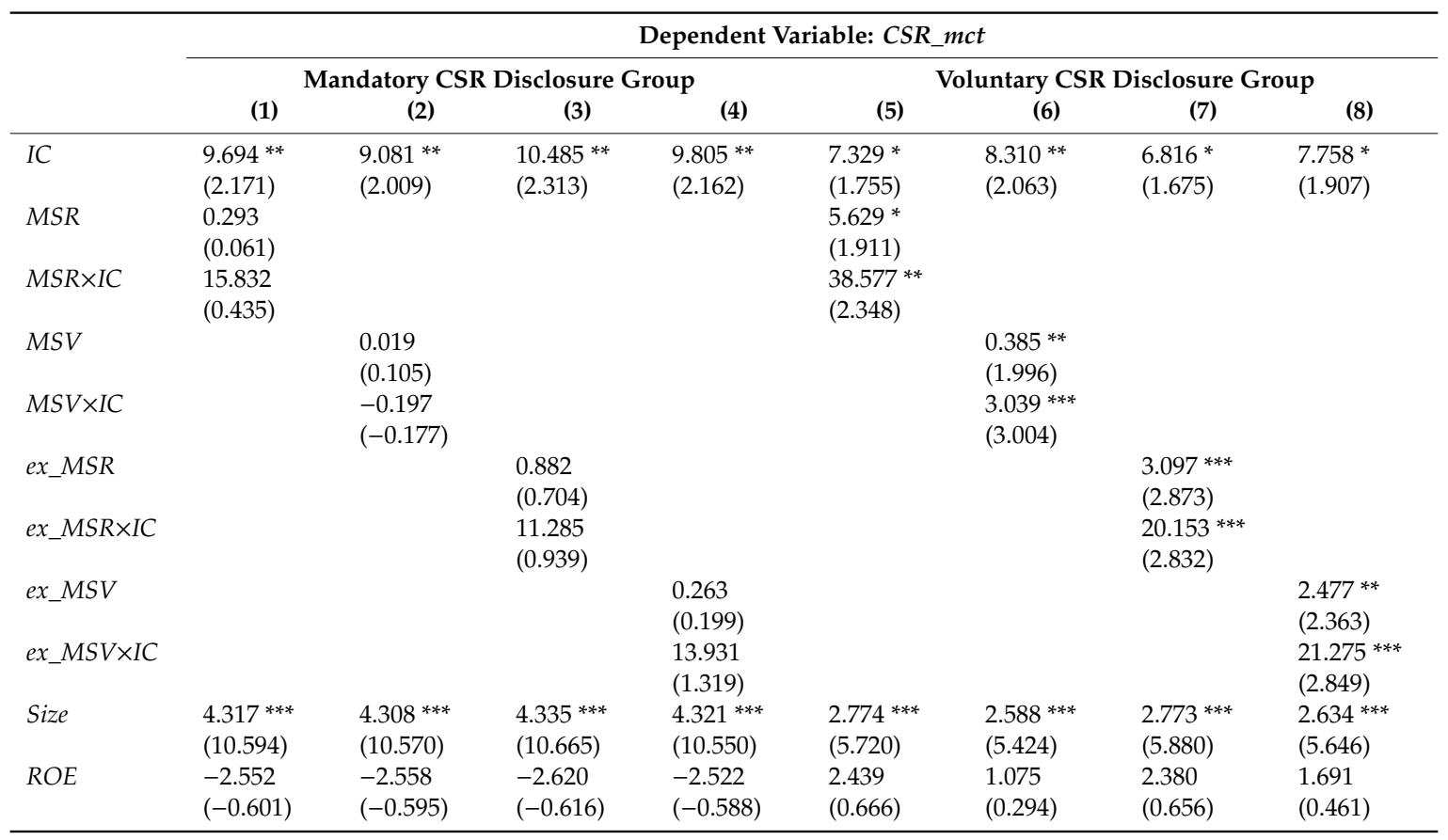


Table A3. Cont.

\begin{tabular}{|c|c|c|c|c|c|c|c|c|}
\hline & \multicolumn{8}{|c|}{ Dependent Variable: $C S R \_m c t$} \\
\hline & \multicolumn{4}{|c|}{ Mandatory CSR Disclosure Group } & \multicolumn{4}{|c|}{ Voluntary CSR Disclosure Group } \\
\hline & (1) & (2) & (3) & (4) & (5) & (6) & (7) & (8) \\
\hline Lev & $\begin{array}{l}-3.505 \\
(-1.133)\end{array}$ & $\begin{array}{l}-3.501 \\
(-1.132)\end{array}$ & $\begin{array}{l}-3.538 \\
(-1.144)\end{array}$ & $\begin{array}{l}-3.578 \\
(-1.160)\end{array}$ & $\begin{array}{l}-3.135 \\
(-1.296)\end{array}$ & $\begin{array}{l}-3.168 \\
(-1.304)\end{array}$ & $\begin{array}{l}-3.184 \\
(-1.321)\end{array}$ & $\begin{array}{l}-3.205 \\
(-1.323)\end{array}$ \\
\hline Age & $\begin{array}{l}-0.051 \\
(-0.514)\end{array}$ & $\begin{array}{l}-0.052 \\
(-0.518)\end{array}$ & $\begin{array}{l}-0.038 \\
(-0.400)\end{array}$ & $\begin{array}{l}-0.044 \\
(-0.453)\end{array}$ & $\begin{array}{l}-0.026 \\
(-0.351)\end{array}$ & $\begin{array}{l}-0.035 \\
(-0.496)\end{array}$ & $\begin{array}{l}-0.010 \\
(-0.148)\end{array}$ & $\begin{array}{l}-0.026 \\
(-0.380)\end{array}$ \\
\hline Growth & $\begin{array}{l}-0.130 \\
(-0.122)\end{array}$ & $\begin{array}{l}-0.119 \\
(-0.111)\end{array}$ & $\begin{array}{l}-0.234 \\
(-0.218)\end{array}$ & $\begin{array}{l}-0.162 \\
(-0.151)\end{array}$ & $\begin{array}{l}-1.428 \\
(-1.388)\end{array}$ & $\begin{array}{l}-1.601 \\
(-1.548)\end{array}$ & $\begin{array}{l}-1.459 \\
(-1.440)\end{array}$ & $\begin{array}{l}-1.481 \\
(-1.413)\end{array}$ \\
\hline Cashflow & $\begin{array}{l}0.046 \\
(1.072)\end{array}$ & $\begin{array}{l}0.046 \\
(1.071)\end{array}$ & $\begin{array}{l}0.045 \\
(1.061)\end{array}$ & $\begin{array}{l}0.045 \\
(1.071)\end{array}$ & $\begin{array}{l}-0.088 \\
(-1.257)\end{array}$ & $\begin{array}{l}-0.089 \\
(-1.303)\end{array}$ & $\begin{array}{l}-0.083 \\
(-1.207)\end{array}$ & $\begin{array}{l}-0.084 \\
(-1.228)\end{array}$ \\
\hline$S O E$ & $\begin{array}{l}2.100^{* *} \\
(2.048)\end{array}$ & $\begin{array}{l}2.117^{* *} \\
(2.124)\end{array}$ & $\begin{array}{l}2.269 * * \\
(2.172)\end{array}$ & $\begin{array}{l}2.153 * * \\
(2.080)\end{array}$ & $\begin{array}{l}2.231 * * \\
(2.190)\end{array}$ & $\begin{array}{l}2.104^{* *} \\
(2.199)\end{array}$ & $\begin{array}{l}2.716^{* * *} \\
(2.601)\end{array}$ & $\begin{array}{l}2.239 * * \\
(2.309)\end{array}$ \\
\hline _cons & $\begin{array}{l}-68.576^{* * *} \\
(-7.146)\end{array}$ & $\begin{array}{l}-67.974 \\
(-7.093)\end{array}$ & $\begin{array}{l}-69.863^{* * *} \\
(-7.278)\end{array}$ & $\begin{array}{l}-68.859 * * * \\
(-7.200)\end{array}$ & $\begin{array}{l}-34.966^{* * *} \\
(-3.187)\end{array}$ & $\begin{array}{l}-30.868 \text { *** } \\
(-2.906)\end{array}$ & $\begin{array}{l}-35.156^{* * *} \\
(-3.299)\end{array}$ & $\begin{array}{l}-31.826 \\
(-3.042)\end{array}$ \\
\hline Year & Yes & Yes & Yes & Yes & Yes & Yes & Yes & Yes \\
\hline Industry & Yes & Yes & Yes & Yes & Yes & Yes & Yes & Yes \\
\hline$N$ & 1696 & 1696 & 1696 & 1696 & 1241 & 1241 & 1241 & 1241 \\
\hline$R^{2}$ & 0.341 & 0.341 & 0.342 & 0.342 & 0.205 & 0.210 & 0.216 & 0.209 \\
\hline Adj. $R^{2}$ & 0.328 & 0.328 & 0.328 & 0.328 & 0.183 & 0.187 & 0.194 & 0.187 \\
\hline
\end{tabular}

Table A4. Robust test 2-Managerial shareholding and CSR.

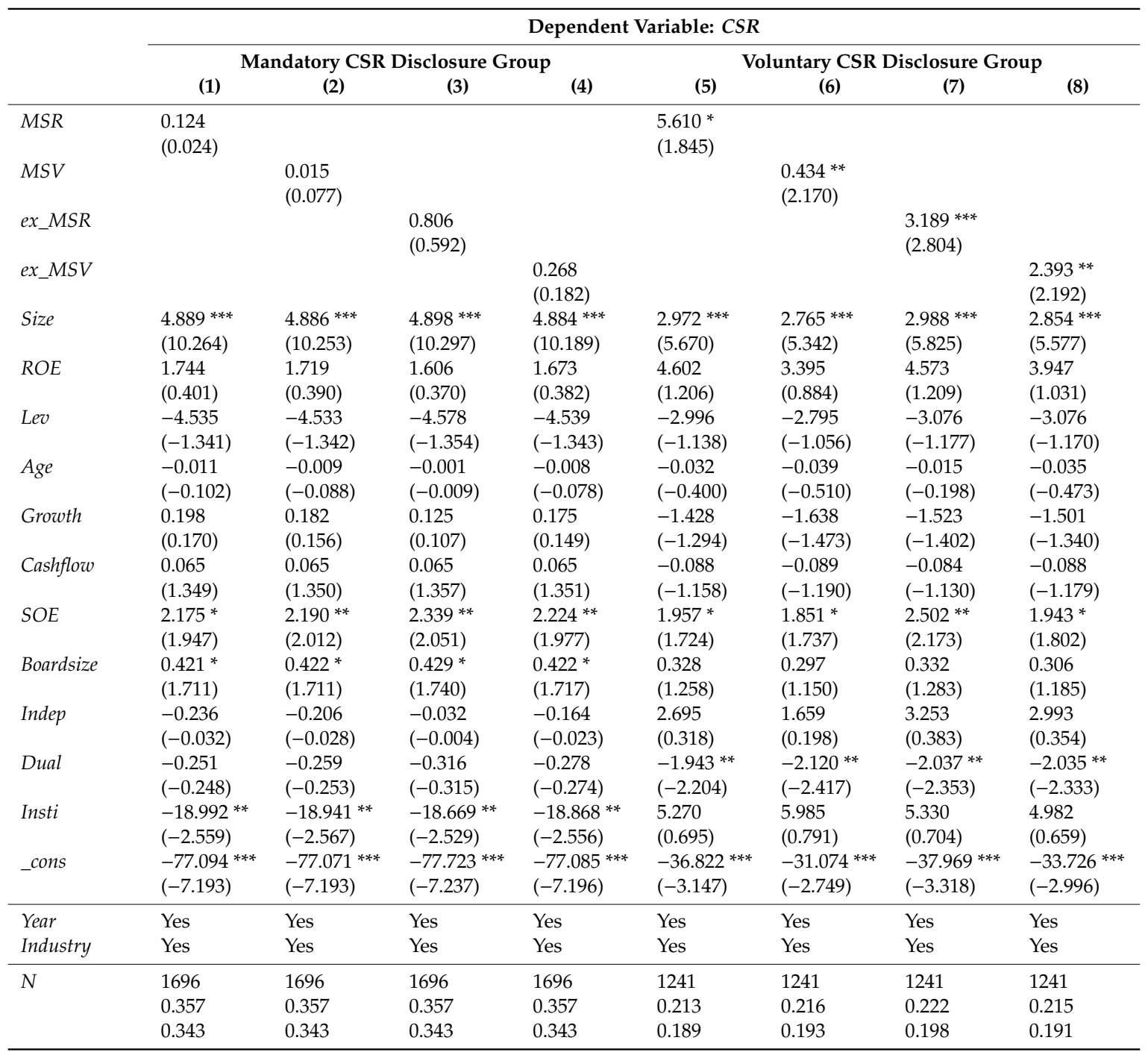


Table A5. Robust test 2-The role of internal control quality.

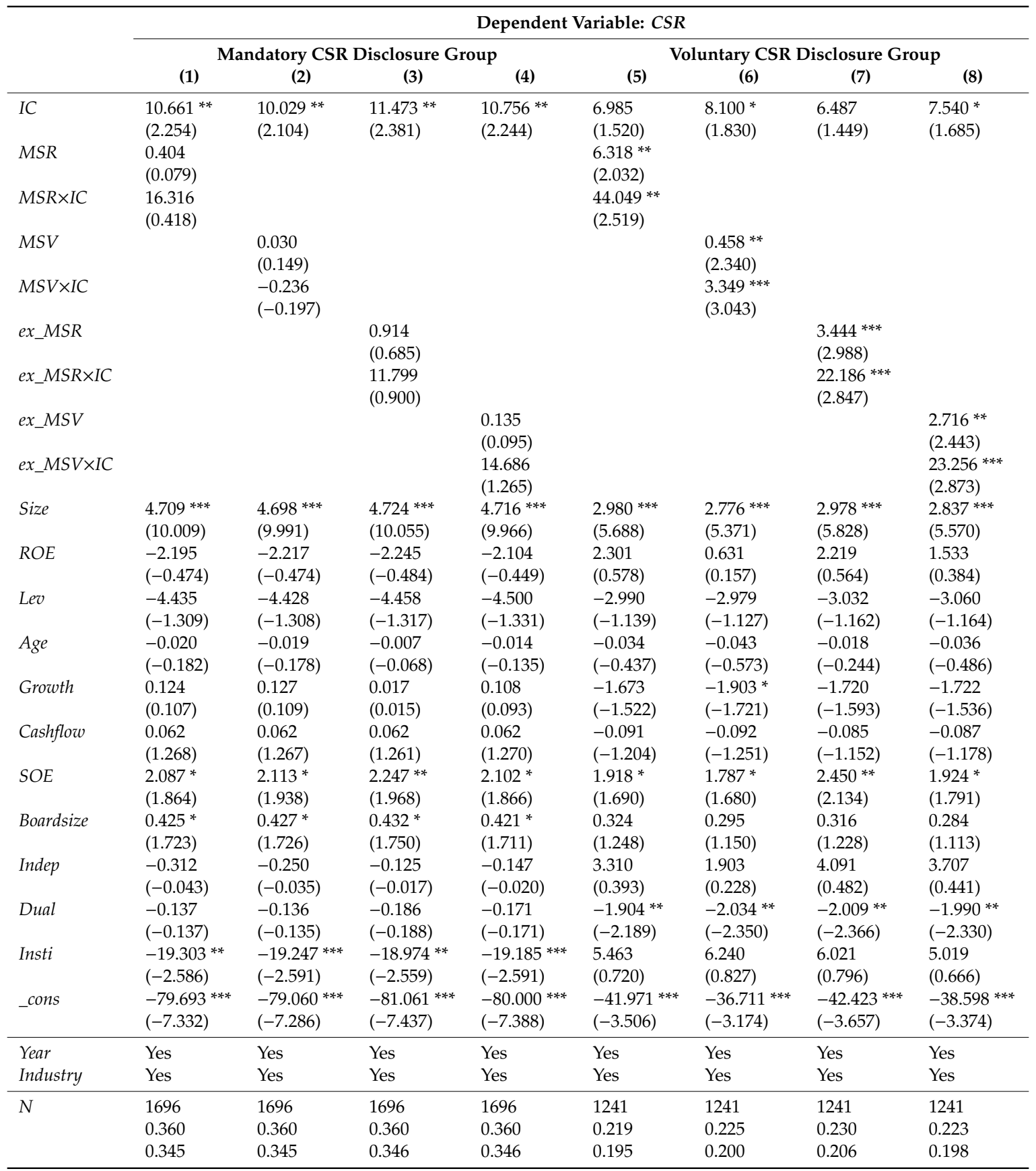

\section{References}

1. Sheldon, O. The social responsibility of management. In The Philosophy of Management, 1st ed.; Sir Isaac Pitman and Sons Ltd.: London, UK, 1924.

2. Panapanaan, V.M.; Linnanen, L.; Karvonen, M.-M.; Phan, V.T. Roadmapping corporate social responsibility in Finnish companies. J. Bus. Ethics 2003, 44, 133-148. [CrossRef]

3. Spiller, R. Ethical business and investment: A model for business and society. J. Bus. Ethics 2000, 27, 149-160. [CrossRef]

4. Qu, J. Corporate Governance, Corporate Social Responsibility Disclosure and Corporate Value. Master's Thesis, Shandong University, Jinan, China, 2018. (In Chinese).

5. Karim, K.; Lee, E.; Suh, S. Corporate social responsibility and CEO compensation structure. Adv. Account. 2017, 40, 27-41. [CrossRef] 
6. Hadley, B. Executive compensation and political sensitivity: Evidence from government contractors. J. Corp. Finance 2016. [CrossRef]

7. Yin, K.; Wang, Y.; Liu, X. Nature of property rights, managerial ownership and social responsibility information disclosure-Evidence from Chinese listed companies. Res. Econ. Manag. 2014, 35, 114-120. (In Chinese) [CrossRef]

8. Li, L.; Ma, X. Executive ownership, internal control and corporate social responsibility. Enterp. Econ. 2018, 37, 133-140. (In Chinese) [CrossRef]

9. Qi, X. Study on the impact of executive compensation and financial performance on corporate social responsibility. Master's Thesis, Guangxi Normal University, Guilin, China, 2018. (In Chinese).

10. Feng, L.; Liao, H.; Song, S. Empirical test of the impact of internal control on corporate social responsibility performance. Stat. Decis. 2015, 31, 175-178. (In Chinese) [CrossRef]

11. Pirvu, C.; Domnisoru, S.; Vinatoru, S. Internal control and social responsibility. In Current Issues in Corporate Social Responsibility: An International Consideration; Idowu, S.O., Sitnikov, C., Simion, D., Bocean, C.G., Eds.; Springer International Publishing: Cham, Switzerland, 2018; pp. 111-124.

12. Chen, D.; Liu, Y. Exploration of internal control failure in pharmaceutical enterprises-Based on the analysis of Changchun vaccine scandal. Commun. Finance Account. 2019, 40, 110-115. (In Chinese) [CrossRef]

13. Albring, S.M.; Xu, X. Management earnings forecasts, managerial incentives, and risk-taking. Adv. Account. 2018, 42, 48-69. [CrossRef]

14. Korczak, P.; Liu, X. Managerial shareholding policies and retention of vested equity incentives. J. Empir. Finance 2014, 27, 116-129. [CrossRef]

15. Rae, K.; Subramaniam, N. Quality of internal control procedures: Antecedents and moderating effect on organizational justice and employee fraud. Manag. Audit. J. 2008, 23, 104-124. [CrossRef]

16. Sun, Z.; Wang, L.; Li, Z.; Zhao, S. When will R\&D investment enhance corporate performance-A study based on the moderating effects of the internal control effectiveness. Soft Sci. 2019, 33, 1-11. (In Chinese) [CrossRef]

17. Hu, M. Managerial power, internal control quality and earnings management. J. Chongqing Univ. (Soc. Sci. Ed.) 2018, 24, 66-76. (In Chinese) [CrossRef]

18. Driver, C.; Thompson, G. Corporate governance and democracy: The stakeholder debate revisited. J. Manag. Gov. 2002, 6, 111-130. [CrossRef]

19. Laczniak, G.R.; Murphy, P.E. Normative perspectives for ethical and socially responsible marketing. J. Macromark. 2006, 26, 154-177. [CrossRef]

20. Frederick, W.C.; Post, J.E.; Davis, K. Business and Society: Corporate Strategy, Public Policy, Ethics; McGraw-Hill Book Co.: New York, NY, USA, 1988; pp. 121-143.

21. Mitchell, R.K.; Agle, B.R.; Wood, D.J. Toward a theory of stakeholder identification and salience: Defining the principle of who and what really counts. Acad. Manag. Rev. 1997, 22, 853-886. [CrossRef]

22. Kuriakose, F. The Role of Information Asymmetry in CSR: An Investigation. Available online: https: //ssrn.com/abstract=2838224 (accessed on 26 February 2016).

23. Brown, W.; Helland, E.; Smith, J. Corporate philanthropic practices. J. Corp. Finance 2006, 12, 855-877. [CrossRef]

24. Zhao, L.; Ruan, X.; Liu, F. The Impact of social responsibility information disclosure on firm financing cost-Empirical evidence based on listed companies in China. J. Guizhou Univ. Finance Econ. 2017, 35, 40-52. (In Chinese)

25. Arouri, M.; Gomes, M.; Pukthuanthong, K. Corporate social responsibility and M\&A uncertainty. J. Corp. Finance 2019, 56, 176-198. [CrossRef]

26. Orlitzky, M. Does firm size comfound the relationship between corporate social performance and firm financial performance? J. Bus. Ethics 2001, 33, 167-180. [CrossRef]

27. Kalay, A. Signaling, information content, and the reluctance to cut dividends. J. Financ. Quant. Anal. 1980, 15, 855-869. [CrossRef]

28. Zahra, S.A.; Oviatt, B.M.; Minyard, K. Effects of corporate ownership and board structure on corporate social responsibility and financial performance. Acad. Manag. Best Pap. Proc. 1993, 1, 336-340. [CrossRef]

29. Friedman, M. Money and income: Comment on Tobin. Q. J. Econ. 1970, 84, 318-327. [CrossRef] 
30. Wang, H.; Lu, X.; Lin, W. The Effect of foreign equity participation, executive ownership, institutional ownership on corporate social responsibility-Based on the empirical test of a-share public companies in China. Account. Res. 2014, 35, 81-87. (In Chinese) [CrossRef]

31. Luo, W.; Wang, J.; Li, H. Political connections, executives' compensation and corporate social responsibility information disclosure. J. Hunan Finance Econ. Univ. 2017, 33, 66-73. (In Chinese) [CrossRef]

32. Cullinan, C.; Mahoney, L.; Roush, P.B. Are CSR activities associated with shareholder voting in director elections and say-on-pay votes? J. Contemp. Account Econ. 2017, 13, 225-243. [CrossRef]

33. Bouslah, K.; Liñares-Zegarra, J.; M'Zali, B.; Scholtens, B. CEO risk-taking incentives and socially irresponsible activities. Br. Account. Rev. 2018, 50,76-92. [CrossRef]

34. Focke, F.; Maug, E.; Niessen-Ruenzi, A. The impact of firm prestige on executive compensation. J. Financ. Econ. 2017, 123, 313-336. [CrossRef]

35. Li, M.; Gu, X. Executive compensation, property rights and corporate social responsibility. Commun. Finance Account. 2018, 31-129. (In Chinese) [CrossRef]

36. Wang, H.; Wu, Z.; Li, W.; Tian, G. Humanistic interpretation and framework reconstruction of internal control. Account. Res. 2011, 32, 59-65. (In Chinese) [CrossRef]

37. Liu, F. Correlation analysis of corporate social responsibility and internal control. Commun. Finance Account. 2012, 33, 62-63. (In Chinese) [CrossRef]

38. Shao, Y. Study on the Relationship between Internal Control Effectiveness, Media Attention and the Quality of Carbon Information Disclosure. Master's Thesis, Capital University of Economics and Business, Beijing, China, 2018. (In Chinese).

39. Drobetz, W.; Merikas, A.; Merika, A.; Tsionas, M.G. Corporate social responsibility disclosure: The case of international shipping. Transp. Res. Part E Logist. Transp. Rev. 2014, 71, 18-44. [CrossRef]

40. Che, X.; Su, Y. Research of corporate social responsibility report, violations and firm value. Bus. Manag. J. 2018, 40, 58-74. (In Chinese) [CrossRef]

41. Huang, C.; Wang, M.; Chang, W. Does international big 4 auditing improve the quality of corporate social responsibility information disclosure? J. Account. Econ. 2017, 31, 89-105. (In Chinese) [CrossRef]

42. Hua, S. Theory Research on Internal Control for Corporate Social Responsibility. Ph.D. Thesis, Ocean University of China, Qingdao, China, 2011. (In Chinese). [CrossRef]

43. Qi, L. The Study on Integrating Social Responsibility into the Building of Internal Control in Construction Enterprises. Master's Thesis, Ocean University of China, Qingdao, China, 2013. (In Chinese). [CrossRef]

44. Zhu, Y.; Sun, Y. The Impact of coupling interaction of internal control and csr on corporate performance-Based on the perspective of stakeholder. Procedia Eng. 2017, 174, 449-455. [CrossRef]

45. Zhang, F. Research on the integration of internal control and social responsibility. Master's Thesis, Yunnan University of Finance and Economic, Kunming, China, 2018. (In Chinese).

46. Xiao, M. Review of motivation, behavior and economic consequences of CSR information disclosure. Mod. Econ. Inf. 2018, 33, 168-169. (In Chinese)

47. Chen, G.; Zeng, X. Determinants of information disclosure of social responsibility on listed companies. J. Hunan Univ. (Soc. Sci.) 2013, 27, 56-62. (In Chinese) [CrossRef]

48. Shen, H.; Jin, T. An analysis of corporate social responsibility disclosure of listed companies in China. J. Audit. Econ. 2006, 22, 84-87. (In Chinese) [CrossRef]

49. Tian, L.; Wang, K. The "masking effect" of social responsibility information disclosure and the crash risk of listed companies-An analysis based on DID-PSM from China. Manag. World 2017, 33, 146-157. (In Chinese) [CrossRef]

50. Wu, M. A Research of Corporate Social Responsibility Information Disclosure and Influencing Factors of Listed Companies in China. Master's Thesis, Nanjing University of Finance and Economics, Nanjing, China, 2010. (In Chinese). [CrossRef]

51. Mzembe, A.N.; Downs, Y. Managerial and stakeholder perceptions of an Africa-based multinational mining company's Corporate Social Responsibility (CSR). Extr. Ind. Soc. 2014, 1, 225-236. [CrossRef]

52. López-González, E.; Martínez-Ferrero, J.; García-Meca, E. Corporate social responsibility in family firms: A contingency approach. J. Clean. Prod. 2019, 211, 1044-1064. [CrossRef]

53. Quan, X.; Wu, S.; Yin, H. Corporate social responsibility and stock price crash risk: self-interest tool or value strategy? Econ. Res. J. 2015, 50, 49-64. (In Chinese) 
54. Kang, C.; Germann, F.; Grewal, R. Washing away your sins? Corporate social responsibility, corporate social irresponsibility, and firm performance. J. Mark. 2015, 80, 59-79. [CrossRef]

55. Frederiksen, T. Corporate social responsibility, risk and development in the mining industry. Resour. Policy 2018, 59, 495-505. [CrossRef]

56. Jahn, J.; Brühl, R. Can bad news be good? On the positive and negative effects of including moderately negative information in CSR disclosures. J. Bus. Res. 2019, 97, 117-128. [CrossRef]

57. Mohd Ghazali, N. Ownership structure and corporate social responsibility disclosure: Some Malaysian evidence. Int. J. Bus. Soc. 2007, 7, 251-266. [CrossRef]

58. Lazonick, W. The value-extracting CEO: How executive stock-based pay undermines investment in productive capabilities. Struct. Chang. Econ. Dyn. 2019, 48, 53-68. [CrossRef]

59. Xu, X.; Tan, J. Effect and the efficiency of corporate governance: A theoretical and empirical study based on behavioral economics. Nankai Bus. Rev. 2014, 17, 36-45. (In Chinese) [CrossRef]

60. Lee, G.; Cho, S.Y.; Arthurs, J.; Lee, E.K. CEO pay inequity, CEO-TMT pay gap, and acquisition premiums. J. Bus. Res. 2019, 98, 105-116. [CrossRef]

61. Li, L.; Wang, Z.; Kan, L. Internal control and corporate social responsibility performance: Mediating effect test based on agency cost. J. Nanjing Audit. Univ. 2019, 16, 28-36. (In Chinese)

62. Dong, Z.; Ma, P. Managerial ownership: Entrenchment or convergence-of-interest-Based on the decisive effect of internal control. J. Xi'an Jiaotong Univ. (Soc. Sci.) 2019, 39, 23-31. (In Chinese) [CrossRef]

63. Shen, H. Corporate characteristics and social disclosure-Evidence from listed companies in China. Account. Res. 2007, 28, 9-16. (In Chinese) [CrossRef]

64. Chiu, S.S.; Sharfman, M. Legitimacy, visibility, and the antecedents of corporate social performance: An Investigation of the instrumental perspective. J. Manag. 2011, 37, 1558-1585. [CrossRef]

65. $\mathrm{Li}, \mathrm{Z}$. Internal control and investor relations management in China: Evidence from the investor relations survey of listed companies. Rev. Account. Control 2013, 34, 45-58. (In Chinese) [CrossRef]

66. Said, R.; Zainuddin, Y.; Haron, H. The relationship between corporate social responsibility disclosure and corporate governance characteristics in Malaysian public listed companies. Soc. Responsib. J. 2009, 5, $212-226$. [CrossRef]

67. Harjoto, M.A.; Jo, H. Corporate governance and CSR nexus. J. Bus. Ethics 2011, 100, 45-67. [CrossRef]

68. Garcia Torea, N.; Fernandez-Feijoo, B.; De la Cuesta, M. Board of director's effectiveness and the stakeholder perspective of corporate governance: Do effective boards promote the interests of shareholders and stakeholders? BRQ Bus. Res. Q. 2016, 19, 246-260. [CrossRef]

69. Lopez-Iturriaga, F.; Foronda, Ó. Corporate social responsibility and large shareholders: An analysis of European firms. SSRN Electron. J. 2009. [CrossRef] 